\title{
The Basic Situation of Modern Nation-State
}

\author{
Ye Liu \\ Institute of Marxist Philosophy, Shanxi University, Taiyuan, China
}

Email address:

liuye@sxu.edu.cn

\section{To cite this article:}

Ye Liu. The Basic Situation of Modern Nation-State. Journal of Political Science and International Relations. Vol. 2, No. 4, 2019 , pp. 86-92. doi: $10.11648 /$ j.jpsir.20190204.12

Received: September 29, 2019; Accepted: October 26, 2019; Published: October 31, 2019

\begin{abstract}
The modern nation-state is a very important and complicated political entity form in today's world. In the foreseeable future, it will still be one of the world's most general and dominant community pattern. Therefore, it has certain academic and practical significance to understand the basic situation of modern nation-state by analyzing and explaining its fundamental definition, core bearing consciousness and legitimacy construction. This paper suggests that modern nation-state as the most common pattern of modern political entity is the product of modern society, which ensuring the existence of the whole ethnic community and all individuals in it. The nation-state has to cohere and unite its people through the dual core of national identity and nationalist ideology. On one hand, national identity has become the operational foundation of modern nation-state and provided the most core cohesion for the establishment, consolidation and development for it. On the other hand, nationalism can be a kind of modern ethnic ideology and social political movement, and also a demand of economic system, a construction of social cultures and feelings. Only on this basis, the nation-state's autonomy and people's survival rights and unique values can be guaranteed, then the legitimacy construction of the nation-state can be realized. And the legitimacy construction of modern nation-state embodies in the enforcement of nationality policy, the protection of national sovereignty and the balance of international order. In the era of nation-state, we have to continuous concern both its broad connotation and its problem domain to grasp the essence of the modern society.
\end{abstract}

Keywords: Modern Nation-state, National Identity, Nationalism, Nationality Policy, Sovereignty, Legitimacy

\section{Introduction}

When we talk about the issue of social formation in the context of the modern world, we always come to the notion of "nation-state". The concepts of nation and state are closely related and intertwine with each other, especially in the historical perspective of the last two centuries, nation and state have never been separated from each other. The word "nation" has both the meanings of countries and ethnic groups. It can be seen that nation and state are two inseparable terms which essentially integrated. The enduring research on nation-state from the angles of political science, sociology, philosophical analysis is because as a political organization the constantly development history of nation-state not only outlined the basic prospect of the world, but also control the changing of the international order. Modern scholars' understandings of nation-state issue focus on the analysis of social conditions, covers multiple perspectives of social economic, culture, politics, ideology, constructivism, etc. Confronting the reality of modern society, this paper analyzes the basic situation of modern nation-state on the basis of historical materialism.

\section{The Definition of Modern Nation-state: The Most Common Pattern of Modern Political Entity}

Nation-state is the most common political entity model in the process of modern history. Since the modern industry civilization, nation-state has become the most important form of people's government that the subject wants to have for a community. For all the people, the term of "nation-state" seems to be a truism, when we mention this word, people will have a rough idea and impression which involves territory, politics, economy, history, language, customs, culture and many other aspects. From the subjective and affective category, nation-state is a "compatriot" community which has common history, common language, common culture, common territory and common sense of identity. From the 
objective standard focusing on the development of society, nation-state is an inevitable outcome and necessary formation of social development when it come into the era of capitalism. It is the consequence of the industrialization, and the carrier of political legitimacy. In the modern sense, nation-state emphasizes not only the sensuous division of kinship, psychology and culture, but also the ruling authority of rational concepts such as politics, law and legality. In the last two centuries, as the worldwide dominant political entity and regime organization form since modern industrial revolution, nation-state provides legitimacy of political sovereignty, economic interests and identity for community, which makes the community members joint together to safeguard and develop their country. As the legal boundary of industrial social community, the nation-state is both the decision of technological development, historical change and political evolution, and the necessity of national emotion and subject identification. In the ultimate sense, the nation-state is a historical construction, its order is an internal build of community functionality which determined by the rational development of human society. We must understand it from a dialectical, critical and nurturing perspective.

First of all, in terms of the emergence and development of the nation-state, it is an inevitable byproduct of modern society. The interpretation of nation-state should be placed in the whole field of human history. Industrialization has enabled the survival of the nation, accompanied which these two closely related categories, nation and state, have gradually combined and become the most important political organization in modern society. We know that before industrialization, the disappearance of nations, groups, cultures and traditions often happened. They were lost in time and disappeared without a trace. So, industrialization is the decisive factor for the survival of modern nation and the creation of nation-state. So to speak, if there is no industrialization which including all existence in the production process, and through the widespread of capitalist industrialization, modernization and globalization in the world, then the modern nation-state will not emerge. Because of industrialization the nation-state can be the most effective form of community to provide its members with a "belonging", that is providing the national identity, national awareness and national cohesion with a legitimacy boundary. It is obvious that industrial development must be given an important position in the analysis of the emergence and development of nation-state. What closely connected with nation-state is the outbreak of the industrial revolution in western countries, and the successful large-scale industrialization, modern economic growth and the unprecedented economic prosperity. It can be said that the nation-state, as the external carrier of politics, economy, culture and science and technology, is the projection of modernity to human society. With industrial revolution, "capitalism's invasion of the world produced the nation-state. That is, produced the relatively mono-cultural, homogeneous, unilinguistic entities that have become the U. N. O. standard pattern of this century."[1] In the modern sense, nation-state, as the most fundamental form of entity in world system, is the most important product of capitalism invading the world, and will "eventually replace all other forms of cultural and political community.'”[2]

Secondly, in terms of the survival of the ethnic group, the nation-state has a special significance. As is known to all, along with modernization spreads outward from the Western Europe core areas to the periphery areas, the world has divided into uneven developmental regions that the developed core areas suppressing the undeveloped periphery areas at different times, degrees and depths. Modern society is a high-tech system, which promotes industrial development and technological progress, but also leads to uneven development. The modern nation-state is born in this circumstance and is restricted by it. "Development favoured the formation of larger competitive entities, the nation-state units."[3] That is to say, "nation-statehood in the new mode was configured by the pressures and constraints of development, in other words, and these ensured that the only entities above a certain threshold of scale had any chance of surviving, or of attaining independence - or indeed, any right to do so."[3] Therefore, in the level of survival, the nation-state ensures the existence of the whole community and all individuals in it. In modern society, it is only through the legitimacy of the nation-state boundaries can ethnic group achieve to independence and autonomy, and only belong to a particular nation can individual has the rights and significance of live. It can be seen that the construction of nation-state should be the creation of social entity of participating, safeguarding and identifying its own national self-determination and state rights. As the most dominant political unit of modern society, nation-state is the primary space of political system and social formation debate, we must realize that we are living in an era of nation-state.

Thirdly, in terms of its type and scale, nation-state can be classified into various categories. Considering the state strength, international status and development level, nation-state can be divided into developed nation-states at the core and developing nation-states at the periphery. Considering whether the group sharing a single common history, culture, language and value, nation-state can be divided into the mono-national states and multinational states, and in the real social conditions most of nation-states are multinational states. Considering the scale and region, nation-state can be divided into large, medium, small and micro nation-states. Nation-states of all types and scales need to build their own distinctive political, economic, cultural, administrative institutions and a military that can defend them. In order to ensure its own viability, the nation-state must have the full autonomy of independent action on the world stage. Therefore, nation-state must establish itself in the international legal status with independent claims and true self management. Only has a positive national consciousness, a purpose to realize its own development without damage other community can nation-state achieve the sustained political stability and self-determination, economic development and autonomy, cultural diversity and identity. 


\section{The Bearing Consciousness of Modern Nation-state: The Dual Core of National Identity and Nationalism}

\subsection{National Identity}

In the course of modern history in the past two centuries, national appeals have gradually gained political dominance, and the issue of national identity has become prominent in the world. Where are the countries' frontiers, who is included in, and what makes people belong to their countries become more and more important. People are becoming more determined and organized in affirming their historical, cultural, religious, ethnic and territorial roots. In other words, people are reaffirming their special identity. Since the industrial revolution in modern times, as the dominant form of political organization of the world, national identity makes community members joint together to maintain and develop their nation-states, which became the core power of modern society. National identity has become the operational foundation of modern nation-state and provided the most core cohesion for the establishment, consolidation and development for modern nation-state. National identity's task is to affirm and protect people's identity politically.

Modern "national identity" is a political legitimacy concept. It is necessary to have national identity in the course of modern nation-state's operation and construction. It is a political standard of modern society and a belief of social community that make a person or group of people different from other people. Finding one's own identity is the way of people distinguishing themselves from other people and proving their uniqueness and value. The state plays a vital role in the recognition and protection of national identity. As the most important institution in the community's operation, state provides political protection for national identity, which is the key point to the sustainable development of human diversity and the carrier of national cohesion. "The reason why we need identity is because people need the sense of belonging."'[4] Capitalism and international competitions are enveloping human society all-dimensionally, and national identity is the most appropriate form of fundamental characteristics for this environment. This kind of legitimacy and centrality of national identity "can generate strong psychological power and bring the sense of security, pride, independent consciousness and self-respect to individuals".[4] In the international society today, it is national identity that provides individuals with the sense of security and belonging. "As for individuals, they cannot develop without nation and state as the basis for their existence."[5] The key to the rationality and legitimacy of the nation-state members is national identity. "To a large extent, it is becoming the most important and effective weapon for countries to defend their own interests in the context of globalization."[6] The deep social utility of national identity can be seen from this.

We know, "Human biological diversity needs to be explored, not denied'... And then, diversity needs some new political defences in order to survive."[3] It can be seen that the political institution of the state plays an important role in the affirmation and protection of national identity: every group seeks to confirm its own identity, and it is the state that provides the legal boundary and organization for national identity. So, what makes national identity so important in the world of modern nation-states? The answer to this question should be put in the field of industrialization, modernization and globalization to explain, that is industrialization makes nations be aware of their survival should be put in the first place. And it is also accompanied with industrialization, these two closely related category, nation and state, gradually combined and became the main political unit in the modern society, as Nairn wrote "before industrialisation this happened all the time: cultures, peoples, traditions would just 'go under', leaving a few puzzling bricks or stones behind if they were lucky."[3] It can be said that in modern society, through capitalist industrialization and the ensuing modernization and globalization, all existences have generalizing in the process of production, and the nation-states are no exception. The modern nation-state is the result of the rapid development of science, technology and capital, which provides its members with a "belonging", that is, a legal boundary for national identity, national consciousness and national cohesion.

Industrialization has a decisive influence on national cohesion, it brings the ideological and conscious level identity of nation-state. Identity is possible because people need the sense of belonging. Industrialization is the key field for the people affiliating with nation-state. As Nairn wrote, "the tendency of capitalism to 'unite, in some measure, the most distant parts of the world, by enabling them to relieve one another's wants, to increase one another's enjoyments, and to encourage one another's industry"'.[3] The rapid development of industry brings the improvement of civilization, but also led to a new world of slavery, which has brought the exploitation and oppression of some groups of people to other groups of people. The political system of industrialization has changed the world and makes the self-esteem nation realizing that they should have self-determined identity and self-governed political mechanism. So, "the decisive identity-mode was 'made' or helped to appear, it seemed a determination of nature rather than the will."'[3] It is the industrialization of capitalism that provides this "help". In the industrial society, the larger the scale of industrial production and the more developed the capitalist market be, the stronger the senses of identity crisis, identification psychology and national cohesion are, and the more the nation-state can exert its control effect in the industrial order. The world market of capitalism and the nation-state thereafter met and shook the agricultural world violently. In this context, the particularity of national identity shows its important role in fighting against the impact of capitalist industrialization, just as Nairn pointed out that "nationality... became the operative, dominant form of identification under the circumstances of modernization; for it...represented effectual adaptation to the weather of industrialisation."[3] It can be seen that the industrial storm has seriously impacted the culture and politics of human society, for dealing with such impact human beings must build 
a united community to fight against, and national identity can precisely provide such cohesive force and ideological identity for it.

Since then, with the development of industrialization, modernization and globalization, the sense of belonging to a specific nation-state has become more and more clear, and the political community structure of the nation-state has more and more carried the cohesive force of human beings in the pluralistic society. We learn from Nairn that " "modernisation' itself is only another word for forever - the ongoing processes of industrialisation, through which in time far greater human and cultural variety will certainly be produced."[3] This diversity requires a border, a specific sense of common belonging and identifying, therefore a national political structure must be in place to provide collective identity to foster common loyalty, and satisfy moral and emotional identification of community members. "Modernity summons us to show our identity passes."[3] The conscious, collective identity can only be meaningful and complete when a common purpose and action emerges. So national identity takes place under the common will and behavior, nationality is not in the genes, but more prominent and inevitable in the structure of the modern world. Nationality is the structural demand of the modern world, and national identity is obvious and unavoidable in the construction of the modern community system. As Nairn put it, "ever since the vast, multi-ethnic recoil against French conquests it is the principle of political nationality which has emerged and re-emerged, as the apparently inevitable form of almost all new states and international state settlements."[3] The nation-state is an indispensable community unit to resist aggression and oppression, and pursue freedom and liberation. The stability and development of this political legitimacy border is the premise of national progress. After the World War I and II, a fact has be very clear: in the environment of globalization and international competition, the nation-state has been so important that without which we cannot solve any post-colonial problems, and the political stability and economic prosperity of the human society and the world order must rely on this unit. National identity protects "our own people", and repels and resists alien forces with the connection of collective cultural spirit. Nation-state, as a modern political system, gives its people reasonable and legal identity, which has naturally adapted to the human social situation of industrialization, modernization and globalization.

\subsection{Nationalism}

As the most important ideology of the nation-state, nationalism is closely related to modernity. "That nationalism is a genuinely modern phenomenon that made its first appearance in Europe shortly before or after 1800 has almost assumed the status of a scholarly consensus. The majority of the leading scholars of nationalism - including Gellner, Hobsbawm, Anderson, Breuilly and Smith - have all linked the emergence of nationalism to specifically modern developments."[7] As a multi-dimensional category, nationalism of modern nation-state needs to be further understood from the aspects of ideology, political movement, economy, culture and the construction standpoint.

Nationalism is an ideology of modern social community. From the common sense and the aspect close to the subject, nationalism is an ideology that people are highly loyal to their nation-state. Hans Kohn pointed out that "nationalism should first and foremost be considered as a state of mind ...... In this state, it reflects the high loyalty of individuals to the nation-state."[8] Nationalism is a set of ideological expression which trying to make a community be regarded as a whole. Through a set of symbols, values and traditions, it makes a community achieve its own identity, and different from others. We can go even further and see nationalism as a political and cultural ideology that pursues its stated goals through a wide range of perspectives and strategies. So, nationalism is the most essential power to create nation-state, it offers the people with emotions and principles of loyalty to their own nation-state. This kind of actual loyalty, love and faith that national members have transcend other kinds of ideologies. In this sense, the nation-state's nationalism ideology is the same thing as patriotism, which represents the awakening of national consciousness.

The nationalism of modern nation-state can be manifested as the political movement for exercising state power. The modern state is the carrier of nation and nationalism. Nationalism is the inevitable accompaniment of state sovereignty. The mutual dynamic effects and integrations between political movements and modern states provided the main impetus of nationalism. Nationalism gives priority to its own nation-state's politics. John Breuilly, a famous British nationalist and ethnographer, regarded nationalism as a "political movements seeking or exercising state power and justifying such action with nationalist arguments. This political theory of nationalism is built upon three basis assertions: (a) there exists a nation with an explicit and peculiar character, (b) the interests and values of this nation take priority over all other interests and values, (c) the nation must be as independent as possible."[9] Here, we see the political nature of nationalism, which, as a modern political theory, supports the national interests or national identity overwhelm all other interests or identities, and thus serves as the ultimate basis for political judgment. The legitimacy of nation-state's political governance comes from the political choice made by the nationalist group of people, that is, to have a country which possessing its own independent autonomy and exercising the power independently within it. "Accordingly, nationalism is better defined as collective action designed to render the boundaries of the nation congruent with those of its governance unit."[10]

Nationalism reflects the social and economic mechanism of the modern world. Needless to say, today's world is an economical society within which capital spreading quickly and industry developing widely, every nation-state is seeking for its own economic prosperity and benefit maximization. Therefore, nationalism projects the different attitude and performance of uneven economic development by different nation-states' development conditions. To be more specific, 
developed nation-states want to keep their leading position, and the developing nation-states want to catch up. This also explains why nationalism is largely confined to modern history, why it is triggered by the inequality among groups, and why it is both inclusive and exclusive. In other words, "Nationalism was the ethical motive force behind the modern economy of growth. The economic process was reoriented very soon after the emergence of national consciousness".[11] On the one hand, industrial capitalism and modernization leading to the direct rule of core areas to the periphery areas that harms the interests of developing nation-states, and thus nationalism as a "mobilization against the unpalatable, humanly unacceptable, truth of grossly uneven development".[12] This become the rational choice of their pursuit of economic development, and this is why nationalism can only be found in the modern world. On the other hand, the new born nationalism of the nation-state has promoted the industrial transformation of the modern economy and become the motivational lever of the industrial revolution. Because when the industrial revolution began, the world's nation-states have consciously positioned themselves to pursue their own economy growth and the sustainable of that growth.

Nationalism is the adhesive of modern nation-states' social culture. Culture is the external manifestation of nation-state. Each nation-state has its own unique cultural formation, including languages, customs, knowledge, beliefs, literatures, arts, myths, legends, historical memories and so on. We know that no matter how small a nation-state is, its constituent units -individuals - are unlikely to know everyone and establish direct connections between every member, so what makes all individuals identify themselves as belonging to the same nation-state and bound together? The answer is that particular nation-state comes together for its particular social culture. "The self-image of nationalism involves the stress of folk, folklore, popular culture, etc. In fact, nationalism becomes important precisely when these things become artificial."[13] Nationalism is closely linked to cultural development, and the social transformation of industrialization has led to the emergence of nationalism. Intellectuals and schools spread this ideology of cultural identity in their own groups. As a form of social political organization, modern nation-state should not only rely on the construction of power and violence, but also on the integration of its own specific cultural structures. Therefore, in the modern nation-states, nationalism should be adopted to bond the relatively discrete social cultures before industrialization, and then to spread the love and loyalty to the nation-states through the language-based national culture and make it continuously spread.

Nationalism is the postnatal constructional product of modern society. Starting from the concept of cultural construction, we can see the important role of the official political and cultural elites for the general popularity of nationalism in the second half of the 19th century, it is the beginning of people were invited to participate in electoral democracy, in this case, the nationalist ideology provides a promising approach. So, nationalism grew out of "the created traditions" which were the product of social engineering and also served the interests of the ruling elites by channeling the energy of newly liberated people. Eric Hobsbawm pointed out that "the 'national question', as the old Marxists called it, is situated at the point of intersection of politics, technology and social transformation.......Nations and their associated phenomena must therefore be analysed in terms of political, technical, administrative, economic and other conditions and requirements.'[14] Benedict Anderson also suggested that, "nationality, or, as one might prefer to put it in view of that word's multiple significations, nation-ness, as well as nationalism, are cultural artefacts of a particular kind...... I will be trying to argue that the creation of these artefacts towards the end of the eighteenth century was the spontaneous distillation of a complex 'crossing' of discrete historical forces."[15] Therefore, we can reach the conclusion that, as a kind of creation or artefact, nationalism is constructed by people who want to establish an independent nation-state which confirmed that it is the product of modern social formation.

So, nationalism can be a kind of modern nation-state ideology, a social political movement, and also can be a demand of economic system, a construction of social cultures and feelings. Just as Michael Cox wrote, "nationalism has throughout continued to retain its power of mobilizing peoples and setting nation against nation".[16] To establish independent modern nation-state is an inevitable process of modern society, we have to understand, process and use of national identity and nationalism properly.

\section{The Legitimacy Construction of Modern Nation-state in Three Dimensions}

Modern countries are emerged in the form of nation-states, and the relations between nation-states constitute the world's political structure. After the establishment of nation-state, how to ensure the legitimacy of the nation-state has become an important issue. As we know, "the primary issue of a nation-state is legitimacy."[4] This kind of legitimacy is the governance legitimacy of political system, with its members believe the current political system is justified, and admit the means, forms and systems the nation-state adopted have the highest authority and undoubted right in its own territory, which embodies in the enforcement of nationality policy, the protection of national sovereignty and the balance of international order.

Firstly, nationality policy. The attribute of a nation is an identity character that reflects the continuity, inheritance and difference of national history. It is a belief in national characteristics. "Nationality", as a kind of resource possessed by ethnic groups and individuals, is based on the blood, language, custom, faith, etc. The individuals in ethnic groups have a sense of worship for their national heroes, a sense of defense for their national borders, and a sense of exclusion for the cultures of other nation-states. After industrial capitalism produced, all nation-states are thrown in the competition of 
development, they must mobilize all the people to join the competition in a most effective, efficient and appealing way. Therefore, the nation-state is bound to use nationalism to mobilize its people, use nationality policy to protect its own interests and resist the other nation-states' political, economic invasion. Nationality policy has demonstrated its vital function in countering the impact of capitalism. "The weather of industrialisation was essentially a storm, one almost violent enough, after the invention of nuclear weapons in the $1940 \mathrm{~s}$, to destroy societal culture itself. Constructing breakwaters against such conditions demanded a certain scale, rigidity, cultural concrete and political armour; in most cases nationality could provide these, and alternative solidarity modes could not."'[3] It can be said that as a form of solidarity, nationality provides the subject with political and cultural protection, and the nationality policy ensures that the community is not destroyed by the storm of industrialization. The nationality policy is the structural demand and inevitable choice of the modern world, and its effect on the community structure and construction is obvious and cannot be ignored. It is obvious that nationality policy is an indispensable group strategy to resist oppression and aggression, pursue freedom and liberation for almost all new nation-states. It is a precondition and principle for national stability, progress and development. In the development of human history, as long as there are contradictions and conflicts between nation-states, the nationality policy must be the leading legitimacy measure adopted by the communities.

Secondly, nation-state sovereignty. Sovereignty is the most symbolic legal standard of nation-state, which is manifested as the supreme political power of a nation-state over the region under its governance. The definition of sovereignty in the Britannica Concise Encyclopedia is that "sovereignty, in political theory, the ultimate overseer, or authority, in the decision-making process of the state and in the maintenance of order." Sovereignty is the freedom of a country without outside control, which means the independence and autonomy of the nation-state. Therefore, the sovereignty of the nation-state is a concept of legitimacy, which internally reflects the highest power of political rule that citizens must obey its will; externally means to deal with international affairs in accordance with the will of its own nation-state without other nation-states' management. The most important symbol of the legitimacy of modern nation-state is sovereignty. In short, a nation-state is a society composed of subjects which occupies delimited territory, has organized government to maintain order and security, protect our interests and avoid external domination. It is with sovereignty that the nation-states become a legitimate entity in the international political arena and form various international relations and systems.

Thirdly, international order. Modern nation-states are in an unprecedented new international environment. In the wave of globalization, the legitimacy of a nation-state ensures its status in international relations and its role in international orders. Although globalization has promoted nation-states to become more closely connected in economy, politics and culture, it still cannot break the boundaries of nation-states, on the contrary, it has promoted nation-state to play an increasingly important legal role in international activities. It can be said that instead of deconstructing the nation-state, globalization has consolidated the legitimacy of modern nation-state in the international order. In today's international order, nation-state has sovereignty legitimacy on politics, development legitimacy on economy and identity legitimacy on culture. It is inevitable to have competitions and frictions between modern nation-states, and divide into developed and developing countries naturally according to the development situation. In this condition, the nation-states should use the means of discussion, negotiation and compromise rather than political ideology and military confrontation to settle the dispute, and on this basis, keeping the bottom line, believing harmony in diversity, actively participating in international affairs, balancing and formulating the international order.

\section{Conclusion}

Nation came into the world history process by integrating with state. Together they constitute "nation-state", the most common and most legal political entity in the modern world, among which "nation" expresses the psychological characteristics of spontaneity of life, a sense of belonging and identity; "state" shows the institutional mechanism of community's organization, plan, system and the concept of law. As a kind of social formation, modern nation-state is the inevitable product of modern society, it ensures the rights and significance of the community and the individuals in it. From the developed countries to the developing countries, and from the large countries to the micro countries, independent sovereign has always been the guarantee of legal status for nation-state's establishment. In the age of industrialization, modernization and globalization, the bearing consciousness of modern nation-state contains the dual core of national identity and nationalism. "Today, we find ourselves in a situation, where across the world, identity has returned as a political force."[17] On the one hand, national identity is the standard to distinguish itself from other groups, and the proof of its uniqueness and value source; on the other hand, nationalism as a kind of multidimensional category, shows the ideological, political, economic, cultural and constructional quality, they both play critical roles for modern nation-state formation. As a primary issue of the nation-state, legitimacy should be discussed from the nationality policy, the sovereignty of the nation-state and the international order. As an indispensable group strategy of all modern nation-states, nationality policy is the prerequisite and principle of national stability, progress and development. The sovereignty of the nation-state internally embodies the highest power of political governance, externally means the indisputable right of independence, which supports the legitimacy of the modern nation-state and ensures the status and the role of the nation-state in international relations and order. It should be noted that we are living in the era of nation-states. The modern nation-state has a broad connotation, and its problem domain is intertwined 
with various categories, such as sociology, political science, ethnology, anthropology, philosophy and history, which deserves our continued attention.

\section{References}

[1] Tom Nairn, The Break-up of Britain: Crisis and Neo-Nationalism, London: NLB, 1977, p. 317.

[2] Tom Nairn and Paul James, Global Matrix: Nationalism, Globalism and State-Terrorism, London: Pluto Press, 2005, p. 76.

[3] Tom Nairn, Faces of Nationalism: Janus Revisited, London: Verso, 1997, pp. 4-190.

[4] Xu Xun, Nationalism, Beijing: Oriental Press, 2014, pp. 34-40.

[5] Ning Fang and Bingquan Wang, On the Ideological Trend of Nationalism, Beijing: Higher Education Press, 2004, p. 22.

[6] Jinxiu Zhai, Interpretation of Post-nationalism in Western Europe: A Multidimensional Perspective in the Context of Tradition and Postmodernism, Jinan: Shandong University Press, 2012, p. 212.

[7] Oliver Zimmer, Nationalism in Europe, 1890-1940, London: Palgrave Macmillan, 2003, p. 5.

[8] Hans Khon, The Idea of Nationalism: A Study of Its Origins and Background, London: The Macmillan Company, 1946, pp. 10-11.

[9] John Breuilly, Nationalism and the State, Manchester: Manchester University Press, 1993, p. 2.

[10] Michael Hechter, Containing Nationalism, Oxford: Oxford University Press, 2000 , p. 7.

[11] Liah Greenfeld, The Spirit of Capitalism: Nationalism and Economic Growth, Cambridge: Harvard University Press, 2003, p. 58.

[12] Tom Nairn, "Scotland and Europe", in New Left Review, Vol. 83,1974 , p. 60

[13] Ernest Gellner, Thought and Change, Chicago: The University of Chicago Press, 1964, p. 162.

[14] Eric Hobsbawm, Nations and Nationalism since 1780: Programme, Myth, Reality, Cambridge: Cambridge University Press, 1992, p. 10.

[15] Benedict Anderson, Imagined Communities: Reflections on the Origin and Spread of Nationalism, London: Verso, 2006, p. 4.

[16] Michael Cox, "Nationalism, nations and the crisis of world order", in International Relations, Vol. 33, No. 2, 2019, p. 247.

[17] Sidharth Luthra and Nivedita Mukhija, The Nationalism Debate, Concerns, and Constitutional Response, in National Law School of India Review, Vol. 30, No. 1, 2018, p. 9. 